\title{
RETINAL ABNORMALITIES IN TRANSGENIC MICE OVEREXPRESSING ABERRANT HUMAN FUS[1-359] GENE
}

Soldatov VO ${ }^{1}$, Kukharsky $\mathrm{MS}^{2}$, Soldatova $\mathrm{MO}^{3}$, Puchenkova OA${ }^{1}$, Nikitina YuA ${ }^{2}$, Lysikova EA², Kartashkina NL ${ }^{4}$, Deykin $\mathrm{AV}^{1}$, Pokrovskiy MV

Belgorod State National Research University, Belgorod, Russia

2 Institute of Physiologically Active Substances, Moscow, Russia

${ }^{3}$ Kursk State Medical University, Kursk, Russia

${ }^{4}$ Sechenov First Moscow State Medical University, Moscow, Russia

Retinal damage is an optional sign in a number of neurodegenerative diseases, including amyotrophic lateral sclerosis (ALS). The aim of this work was to assess the structural and functional state of the retina in a murine model of ALS caused by overexpression of the aberrant FUS protein [1-359]. The retinal examination was carried out on 12 transgenic and 13 wild-type mice of 2.5-3 months of age. The study revealed not statistically significant higher level of ophthalmoscopic violations in FUS[1-359] mice. Moreover, gene expression assay confirmed an increased expression of the inflammatory genes Vegfa, /11b, I/6, Icam 1, Tnfa. However, despite the detected structural and functional abnormalities, western blot analysis and quantitative PCR did not detect the expression of the protein and mRNA products of the FUS transgene in the retina of FUS[1-359] mice.

Keywords: FUS protein, transgenic mice, ALS, retinopathy, inflammation

Funding: the study was carried out with the financial support of the Russian Foundation for Basic Research within the framework of the scientific project № 19-315-90114.

Author contribution: Soldatov VO - the main idea, design of the experiment, ophthalmoscopy, writing an article, design of primers for gene expression assay; Kukharsky MS — the main idea, design of the experiment, writing an article, western blot analysis; Soldatova MO — RNA isolation, qPCR; Puchenkova OA — retina and spinal cord collection, RNA extraction, qPCR; Nikitina YuA — preparation of animal populations, genotyping, western blot analysis; Lysikova EA — preparation of animal populations, genotyping, western-blot analysis, writing an article; Kartashkina NL — interpretation and scoring of ophthalmoscopic picture; Deykin AV consultation on the main idea and design of the study; Pokrovskiy MV — consultation on the main idea and design of the study.

Compliance with ethical standards: animal procedures were approved by the local ethics committee of the Belgorod State National Research University (protocol № 5 / 19-25 dated september 25. 2019). All manipulations were carried out in compliance with the requirements of the International Recommendations of European Convention for the Protection of Vertebrate Animals used for Experimental and Other Scientific Purposes (1997).

Correspondence should be addressed: Vladislav O. Soldatov Pobedy, 85, 308015, Belgorod; pharmsoldatov@gmail.com

Received: 19.08.2021 Accepted: 28.08.2021 Published online: 31.08.2021

DOI: $10.24075 /$ brsmu.2021.043

\section{РЕТИНАЛЬНЫЕ АНОМАЛИИ У ТРАНСГЕННЫХ МЫШЕЙ, СУПЕРЭКСПРЕССИРУЮЩИХ АБЕРРАНТНЫЙ ЧЕЛОВЕЧЕСКИЙ ГЕН FUS[1-359]}

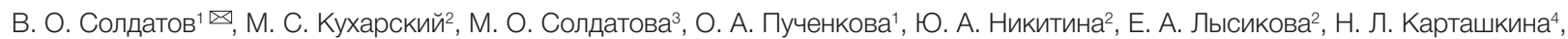
А. В. Дейкин ${ }^{1}$, М. В. Покровский

Белгородский государственный национальный исследовательский университет, Белгород, Россия

${ }^{2}$ Институт физиологически активных веществ, Москва, Россия

${ }^{3}$ Курский государственный медицинский университет, Курск, Россия

${ }^{4}$ Первый Московский государственный медицинский университет имени И. М. Сеченова, Москва, Россия

Повреждение сетчатки является неклассическим симптомом ряда нейродегенеративных заболеваний, включая боковой амиотрофический склероз (БАС). Целью работы было оценить морфофункциональное состояние сетчатки в мышиной модели БАС, связанной с суперэкспрессией аберрантного белка FUS[1-359]. Исследование проводили на 12 трансгенных и 13 диких мышах 2,5-3-месячного возраста. Выявлено, что трансгенные мыши демонстрируют выраженную, но не достигающую статистической значимости тенденцию к развитию офтальмоскопических аномалий сетчатки. Кроме того, молекулярно-биологический анализ подтвердил увеличение экспрессии провоспалительных генов Vegfa, I/1b, /l6, Icam1, Tnfa. При этом, несмотря на обнаруженные структурные и функциональные аномалии, вестерн-блот анализ и количественная ПЦР не выявили экспрессию белкового и мPHK продукта трансгена FUS в сетчатке мутантных мышей.

Ключевые слова: белок FUS, трансгенные мыши, БАС, ретинопатия, воспаление

Финансирование: исследование выполнено при финансовой поддержке РФФИ в рамках научного проекта №19-315-90114.

Вклад авторов: В. О. Солдатов - разработка идеи и дизайна эксперимента, проведение офтальмоскопии, написание статьи, подбор праймеров для оценки экспрессии генов; М. С. Кухарский - разработка идеи и дизайна эксперимента, написание статьи, проведение иммуноблотинга; М. О. Солдатова выделение РНК, проведение ПЦР в реальном времени; О. А. Пученкова - забор материала для молекулярно-биологических исследований, выделение РНК, проведение ПЦР в реальном времени; Ю. А. Никитина - подготовка популяции животных, генотипирование, проведение иммуноблотинга; Е. А. Лысикова - подготовка популяции животных, генотипирование, написание статьи; Карташкина Н. Л. — описание офтальмоскопической картины, написание статьи; А. В. Дейкин - консультация по основной идее и дизайну исследования; М. В. Покровский — консультация по основной идее и дизайну исследования.

Соблюдение этических стандартов: исследование одобрено локальным этическим комитетом Белгородского гоударственного национального исследовательского университета (протокол № 5/19-25 от 25 сентября 2019 г.), проведено с соблюдением требований Международных рекомендаций Европейской конвенции по защите позвоночных животных, используемых при экспериментальных исследованиях (1997).

$\bigotimes$ Для корреспонденции: Владислав Олегович Солдатов ул. Победы, д. 85, 308015, г. Белгород; zinkfingers@gmail.com

Статья получена: 19.08.2021 Статья принята к печати: 28.08.2021 Опубликована онлайн: 31.08.202

DOI: $10.24075 /$ vrgmu.2021.043 
The retina is the most accessible for examination part of the nervous system and it is one of the most vulnerable sensory tissues. Such properties make the study of neurodegeneration ophthalmic correlates highly relevant, opening up opportunities for improving the diagnostics and study of neurodegenerative processes. Due to embryonic commonality and similarity of proteomic composition, the retina can serve as a platform for the development of pathological cascades the central nervous system is prone to [1]. In particular, retinal damage was found in amyotrophic lateral sclerosis (ALS) [2, 3], a disease caused by accumulation of insoluble protein aggregates leading to progressive death of motor neurons [4].

Protein inclusions in ALS have a complex composition and can consist of various proteins, such as RNA-binding proteins or the antioxidant enzyme superoxide dismutase 1, as well as neurofilaments or ubiquitin [5]. In 5\% of familial cases, ALS is associated with the accumulation of aggregates, the main component of which is the FUS protein. One of the cause for the development of FUS proteinopathy is mutations in the nuclear localization signal (NLS) domain and the leak of the protein from the nucleus into the cytoplasm, where it is prone to form insoluble aggregates [6].

With all this background the aim of this study was to assess the relationship between neuronal expression of the pathological form of the FUS protein and the activation of several pathological pathways in the retina.

\section{METHODS}

\section{Animals}

Transgenic mice carrying the sequence of the aberrant human FUS gene encoding a protein with artificially truncated NLS (FUS[1-359]) [7] were used as a model recapitulating FUS proteinopathy. The FUS[1-359] murine model is characterized by progressive paralysis with onset at the age of 3-4 months accompanied by the development of morphological and molecular signs of neurodegeneration, including neuronal death and neuroinflammation [8].

The study was carried out on 25 CD-1 mice (both sexes), 12 of which were FUS hemizygotes, and 13 served as wild-type controls. The mice were kept in conditions of constant access to water and food. Light cycle $-12 \mathrm{~h} / 12 \mathrm{~h}$, illumination - 40-50 lx, temperature $-23 \pm 1{ }^{\circ} \mathrm{C}$, humidity $-42 \pm 5 \%$. At the age of 80-90 days, mice were sedated (Zolazepam + Tiletamine + Xylazine) for ophthalmoscopy. A brief clinical examination performed before sedation allowed to exclude animals with signs of inflammatory changes in the anterior chamber of the eyeball. Ophthalmoscopic examination was performed after application of $1 \%$ atropine sulfate. To perform quantitative objective analysis, the ophthalmologist assessed the fundus picture on a point scale from 0 to 5 , where 0 points - no violations, and 5 points severe abnormalities. Ophthalmoscopy scoring results presented as $\mathrm{M} \pm \mathrm{SD}$; statistical significance for intergroup differences was challenged using the Kruskell-Wallis test. After ophthalmoscopic examination, the animals were euthanized with an overdose of anesthesia for further collection of biomaterial: totally 24 retinal samples were taken from 6 animals from each group for gene expression assay, and 8 retinas and 4 lumbar spinal cord samples were collected from 4 animals for western blot analysis.

\section{Quantitative PCR}

Contralateral retinas from each animal were pulled and incubated for 15 min in ExtractRNA solution (Evrogen; Russia).
After lysis of the sample in the reagent, it was subjected to chloroform extraction. The formed RNA precipitate was washed sequentially with isopropyl alcohol and $70 \%$ ethanol. The resulting precipitate was diluted in $20 \mu \mathrm{L}$ of water, and the concentration of the isolated RNA $(\sim 200 \mathrm{ng} / \mu \mathrm{L})$ was measured using an IMPLENNanoPhotometer ${ }^{\circledast}$ spectrophotometer (Implen; Germany). Reverse transcription was performed using the MMLVRTSK021 kit in accordance with the manufacturer's protocol (Evrogen; Russia).

Primers for quantitative PCR were designed with use of Primer-BLAST resource (NCBI) in compliance with the following requirements: 1) melting temperature $59-61^{\circ} \mathrm{C}$; 2) one of the primers in a pair should span exon-exon junction; 3) forward and reverse primers should not form auto- and cross dimers; 4) the size of the PCR product should be from 95 to $200 \mathrm{bp}$; the primers must be specific to the maximum number of gene transcripts.

Quantitative PCR was performed in a BioRad CFX96 amplifier using the SYBR ${ }^{\circledR}$ Green Master Mix intercalating dye (Bio-Rad Laboratories, Inc .; USA) and oligonucleotide primers (Evrogen; Russia) (Table 1). The expression level of genes of interest (GOI) was assessed relative to the housekeeping genes (HKG) Gapdh and Actb. Expression at a specific point was calculated using the formula: Gene expression $=2^{\wedge}[(\mathrm{Ct}(\mathrm{HKG})$ $-\mathrm{Ct}(\mathrm{GOI})]$.

\section{Western blot}

Retinal samples were pulled from two animals belonging to the same group. After separation in the gel, the proteins were transferred by semi-dry electroblotting onto a Hybond-P polyvinylidene fluoride membrane (Cytiva; UK) pretreated with $100 \%$ methanol, washed with MilliQ water, and soaked in transfer buffer containing $25 \mathrm{mM}$ Tris, $0.15 \mathrm{mM}$ glycine and $20 \%$ methanol. Then the membrane with gel placed between tightly pressed two sheets of soaked 3MM Wathman paper and transferred into in a semi-dry blotter (GE Healthcare Amersham; USA) allowing proteins to diffuse to the membrane for $30 \mathrm{~min}$ at $50 \mathrm{~mA}(1.2 \mathrm{~mA}$ by $1 \mathrm{~cm} 2)$. After electroblotting, the membrane was washed in Tris-Tween buffer (TTB; $50 \mathrm{mM}$ Tris- $\mathrm{HCl} \mathrm{pH} \mathrm{7.4,} 150 \mathrm{mM} \mathrm{NaCl}, 0.1 \%$ Tween-20) 3 times for 5 min. The membrane was blocked in a $4 \%$ solution of nonfat dry milk in TTB for $1 \mathrm{~h}$ at room temperature, then incubated with primary antibodies in the same solution at $4{ }^{\circ} \mathrm{C}$ overnight. After incubation with primary antibodies, the membrane was washed in TTB 3 times for 5 min and incubated with secondary antibodies for $1.5 \mathrm{~h}$ at room temperature, and then rewashed in TTB 3 times for $5 \mathrm{~min}$. Detection of specific binding of antibodies was performed using ECL Plus reagents (Cytiva; UK) according to the manufacturer's instructions. X-ray film was used to detect chemiluminescence. Semi-quantitative assay of the westerns was performed using densitometric analysis using a BioSpectrum AC Chemi HR410 instrument and Vision Works LS software (UVP; Great Britain). When carrying out densitometric analysis, the specific signal from the analyzed protein was normalized in relation to the signal from $\beta$-actin (after the membrane reincubation with the corresponding antibodies) for each lane separately.

\section{RESULTS}

FUS[1-359] transgenic mice show mild ophthalmoscopic abnormalities.

In both groups, some of the animals were found to have vascular anomalies and edema of the optic disc, which is 
Table 1. Primers, used for gene expression assay

\begin{tabular}{|l|c|c|c|}
\hline \multicolumn{1}{|c|}{ Target gene } & Forward primer sequence & Reverse primer sequence & Product length, b.p. \\
\hline Actb & 5'-CGC AGC CAC TGT CGA GTC-3' & 5'-GCC CAC GAT GGA GGG GAA TA-3' & 195 \\
\hline Gapdh & 5'-AGG AGA GTG TTT CCT CGT CC-3' & 5'-TGA GGT CAA TGA AGG GGT CG-3' & 145 \\
\hline Icam1 & 5'-CAT GCC GCA CAG AAC TGG AT-3' & 5'-GGT GTC GAG CTT TGG GAT GG-3' & 116 \\
\hline II6 & 5'-AAA GCC AGA GTC CTT CAG AGA GA-3' & 5'-TGG AAA TTG GGG TAG GAA GGA CT-3' & 100 \\
\hline II1b & 5'-GCC ACC TाT TGA CAG TGA TGAG-3' & 5'-GAC AGC CCA GGT CAA AGG TT-3' & 95 \\
\hline Tnfa & 5'-ACT GAA CTT CGG GGT GAT CG-3' & 5'-ACT TGG TGG TTT GTG AGT GTG-3' & 105 \\
\hline Vegfa & 5'-GCA CTG GAC CCT GGC TTT AC-3' & 5'-CCA CCA GGG TCT CAA TCG GA-3' & 152 \\
\hline Bdnf & 5'-CCT GCA TCT GTT GGG GAG AC-3' & 5'-GCC TTG TCC GTG GAC GTT T-3' & 175 \\
\hline Atg7 & 5'-GCG GCG ACA GCA TTA GGA TT-3' & 5'-ATG GCA GGA AAG CAG TGT GG-3' & 118 \\
\hline Atg5 & 5'-TCA GCT CTT CCT TGG AAC ATC AC-3' & 5'-AAG TGA GCC TCA ACC GCA TC-3' & 95 \\
\hline Bax & 5'-CGA GAG GTC TTC TTC CGG GT-3' & 5'-TCT TGG ATC CAG ACA AGC AGC-3' & 197 \\
\hline Bcl2 & 5'-CTG GGA TGC CTT TGT GGA ACT-3' & 5'-GGC AGG TTT GTC GAC CTC A-3' & 155 \\
\hline
\end{tabular}

routine finding for CD-1 mice $[9,10]$. Statistical analysis did not reveal significant differences between transgenic and wildtype animals; however, FUS[1-359] mice showed a tendency towards more pronounced violations in all studied parameters (Fig. 1).

\section{Truncated FUS is not expressed in the retina}

Western blot analysis did not reveal the presence of a FUSimmunopositive signal in the retinal tissues of transgenic mice (Fig. 2). Furthermore, quantitative PCR also did not detect FUS at the mRNA level. Thus, expression assay did not confirm retinal expression of the transgene at either the transcriptome or protein levels.

\section{Transgenic FUS[1-359] mice are characterized by increased expression of proinflammatory genes in the retina}

Gene expression assay found increased levels of proinflammatory factors Vegfa, Icam1, I/6, $/ 11 \mathrm{~b}$, and Tnfa in the retina of transgenic FUS[1-359] mice. No pronounced changes in the expression of genes related to neuroplasticity (Bdnf), autophagy (Atg7, Atg5), and regulation of apoptosis (Bax, Bcl2) were found (Fig. 3).

A WT
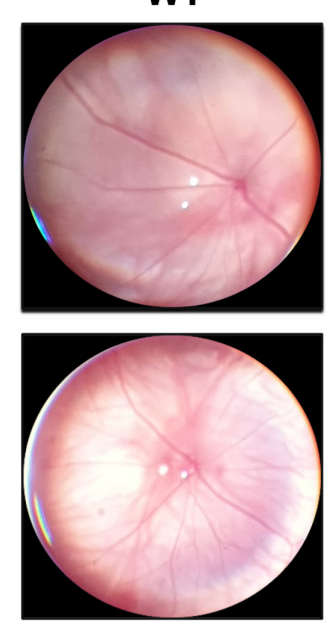

FUS
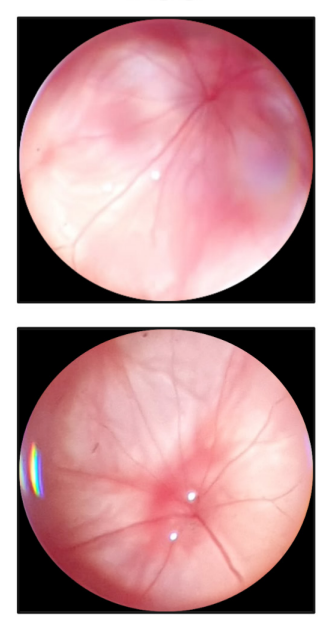

B

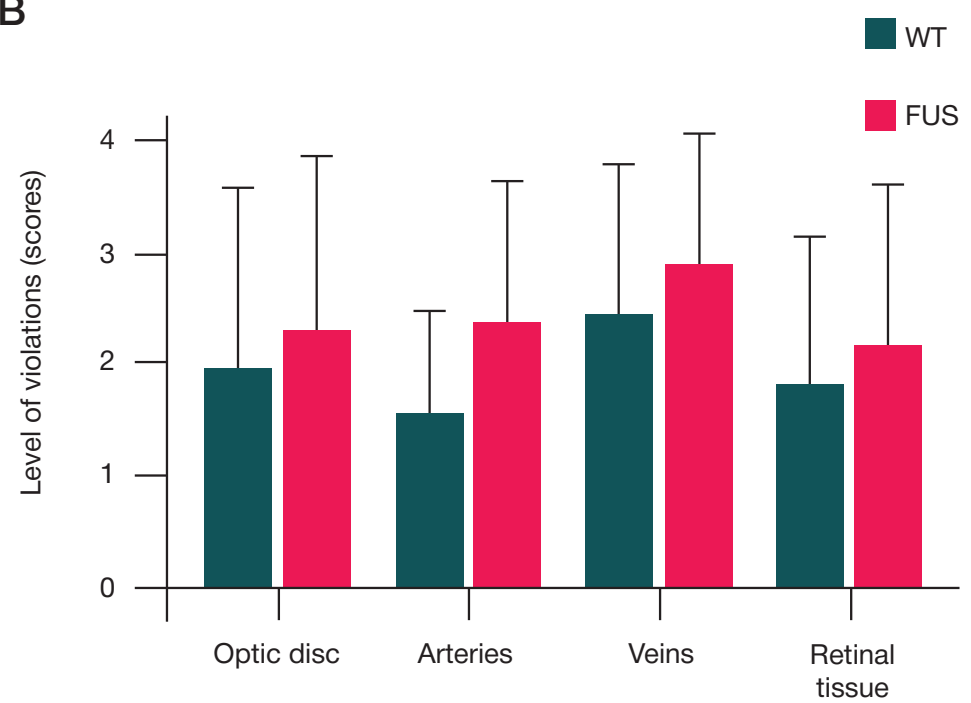

Fig. 1. Results of ophthalmoscopic examination. A. Representative ophthalmoscopic pictures of experimental animals. B. Results of scale scoring of ophthalmoscopic picture

\section{DISCUSSION}

Retinal involvement has been found in various neurodegenerative diseases, including Alzheimer's disease [11], Parkinson's disease [12, 13], and frontotemporal dementia [14]. Not surprisingly, mild ophthalmic abnormalities are also a frequent non-motor symptom of ALS [15]. Among typical clinical findings, color vision impairment [16], as well as thinning of the retina [17] and macula [18-20], are described.

In our study, we did not find significant differences in the severity of ophthalmoscopic changes in the studied animals. Nevertheless, for all studied parameters, an obvious tendency towards more pronounced disorders was revealed in transgenic FUS[1-359] mice. Particularly bright differences were found in relation to the retinal vasculature, which is consistent with the results of the previous report [21].

Since transgene is not expressed in the retina, we aimed to elucidate the mechanisms of retinal degeneration by studying the activity of the most common molecular pathways of neurodegenerative damage to motor neurons. In this regard, as the primary targets we focused on genes related to inflammation, apoptosis, and autophagy. Although pathways of autophagy [22-24] and apoptosis [25] are deeply involved in 
Retina Spinal cord

\begin{tabular}{lllll}
\hline FUS & WT & FUS & WT & FUS \\
\end{tabular}

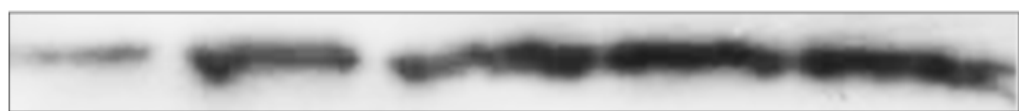

Fig. 2. Absence of truncated FUS protein in retinal tissues of transgenic mice

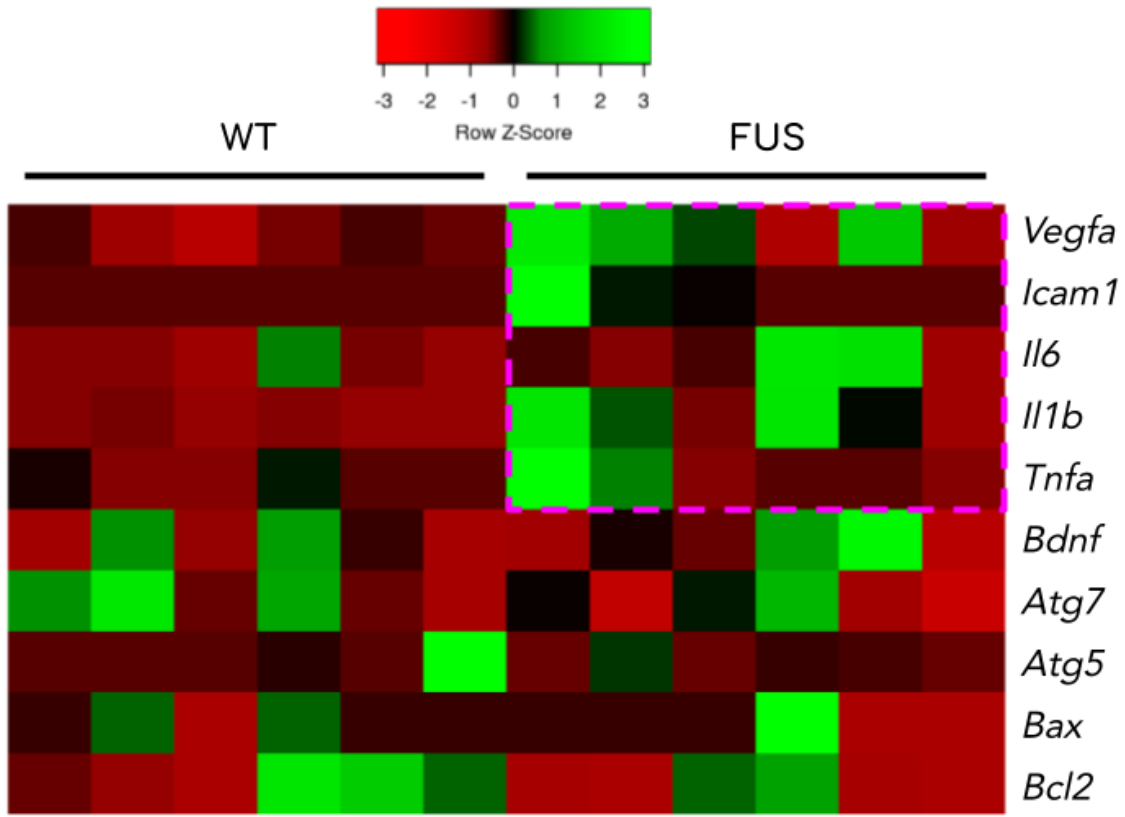

Fig. 3. Normalized heatmap for relative expression of genes related to inflammation (Vegfa, Icam1, I/6, II1b, and Tnfa), neuroplasticity (Bdnf), autophagy (Atg7, Atg5), and regulation of apoptosis (Bax, Bcl2)

ALS as confirmed by various in vivo and in vitro studies, we did not find changed expression of genes Atg7, Atg5, Bax, Bc/2. However, the expression of the Vegfa, Icam1, I/6, I/1 b, and Tnfa genes was altered markedly, indicating the role of inflammation in the mechanisms of retinal degeneration in FUS[1-359] mice. These findings are consistent with previous results regarding the dramatic role of inflammatory activation (and its pharmacological suppression) in the FUS[1-359] mouse model $[26,27]$.

Thus, despite truncated FUS protein is not expressed in retinal tissue, transgenic animals show signs of retinal abnormalities. Potential mechanisms of damage to the eye fundus may include activation of microglia [28], vascular regression [20], and neuro-phthalmic interactions through the glymphatic system [29].

\section{CONCLUSIONS}

The study has demonstrated that transgenic FUS[1-359] mice are prone to the development of structural and functional abnormalities of the eye fundus, despite the absence of transgene expression in the retina. Further detailing of identified violations can highlight the most significant pathways of FUSassociated retinopathy.

\section{References}

1. Yap TE, Balendra SI, Almonte MT, Cordeiro MF. Retinal correlates of neurological disorders. Ther Adv Chronic Dis. 2019; 10 : 2040622319882205. doi:10.1177/2040622319882205

2. Cerveró A, Casado A, Riancho J. Retinal changes in amyotrophic lateral sclerosis: looking at the disease through a new window. J Neurol. 2021; 268 (6): 2083-9. DOI: 10.1007/s00415-01909654-w.

3. Rojas P, de Hoz R, Ramírez Al, et al. Changes in Retinal OCT and their correlations with neurological disability in early ALS Patients, a Follow-Up Study. Brain Sci. 2019; 9 (12): 337. DOI: 10.3390/ brainsci9120337.

4. Zarei S, Carr K, Reiley L, Diaz K, Guerra O, Altamirano PF, et

al. A comprehensive review of amyotrophic lateral sclerosis. Surg Neurol Int. 2015; 16 (6): 171. DOI: 10.4103/2152-7806.169561.

5. Batra G, Jain M, Singh RS, Sharma AR, Singh A, Prakash A, et al. Novel therapeutic targets for amyotrophic lateral sclerosis. Indian J Pharmacol. 2019; 51 (6): 418-25. DOI: 10.4103/ijp.IJP_823_19.

6. Zou ZY, Che CH, Feng SY, Fang XY, Huang HP, Liu CY. Novel FUS mutation Y526F causing rapidly progressive familial amyotrophic lateral sclerosis. Amyotroph Lateral Scler Frontotemporal Degener. 2021; 22 (1-2): 73-79. DOI: 10.1080/21678421.2020.1797815.

7. Shelkovnikova TA, Peters OM, Deykin AV, et al. Fused in sarcoma (FUS) protein lacking nuclear localization signal (NLS) and major RNA binding motifs triggers proteinopathy and severe motor 
phenotype in transgenic mice. J Biol Chem. 2013; 288 (35): 25266-274. DOI: 10.1074/jbc.M113.492017.

8. Funikov SY, Rezvykh AP, Mazin PV, Morozov AV, Maltsev AV, Chicheva MM, et al. FUS(1-359) transgenic mice as a model of ALS: pathophysiological and molecular aspects of the proteinopathy. Neurogenetics. 2018; 19 (3): 189-204. DOI: 10.1007/s10048-018-0553-9.

9. Mukaratirwa S, Petterino C, Naylor SW, Bradley A. Incidences and Range of Spontaneous Lesions in the Eye of Crl:CD-1(ICR) BR Mice Used in Toxicity Studies. Toxicol Pathol. 2015; 43 (4): 530-5. DOI: 10.1177/0192623314548767.

10. De Groef L, Dekeyster E, Geeraerts E, Lefevere E, Stalmans I, Salinas-Navarro M, et al. Differential visual system organization and susceptibility to experimental models of optic neuropathies in three commonly used mouse strains. Exp Eye Res. 2016; 145: 235-47. DOI: 10.1016/j.exer.2016.01.006.

11. Hart NJ, Koronyo Y, Black KL, Koronyo-Hamaoui M. Ocular indicators of Alzheimer's: exploring disease in the retina. Acta Neuropathol. 2016; 132 (6): 767-87. DOI: 10.1007/s00401-0161613-6.

12. Mohana Devi S, Mahalaxmi I, Aswathy NP, Dhivya V, Balachandar V. Does retina play a role in Parkinson's Disease? Acta Neurol Belg. 2020; 120 (2): 257-65. DOI: 10.1007/s13760-020-01274-w.

13. Huang L, Zhang D, Ji J, Wang Y, Zhang R. Central retina changes in Parkinson's disease: a systematic review and meta-analysis. J Neurol. 2020; 10. DOI: 10.1007/s00415-020-10304-9.

14. Harrison IF, Whitaker R, Bertelli PM, O'Callaghan JM, Csincsik L, Bocchetta $\mathrm{M}$, et al. Optic nerve thinning and neurosensory retinal degeneration in the rTg4510 mouse model of frontotemporal dementia. Acta Neuropathol Commun. 2019; 7 (1): 4. DOl: 10.1186/s40478-018-0654-6.

15. Soldatov VO, Kukharsky MS, Belykh AE, Sobolev AM, Deykin AV. Retinal Damage in Amyotrophic Lateral Sclerosis: Underlying Mechanisms. Eye Brain. 2021; 13: 131-46. DOI: 10.2147/ EB.S299423.

16. Boven L, Jiang QL, Moss HE. Diffuse colour discrimination as marker of afferent visual system dysfunction in amyotrophic lateral sclerosis. Neuroophthalmology. 2017; 41 (6): 310-4. DOl: 10.1080/01658107.2017.1326153.

17. Rohani M, Meysamie A, Zamani B, Sowlat MM, Akhoundi FH. Reduced retinal nerve fiber layer (RNFL) thickness in ALS patients: a window to disease progression. J Neurol. 2018; 265 (7): 155762. DOI: 10.1007/s00415-018-8863-2.

18. Fawzi AA, Simonett JM, Purta P, et al. Clinicopathologic report of ocular involvement in ALS patients with C9orf72 mutation. Amyotroph Lateral Scler Frontotemporal Degener. 2014; 15 (7-8):

\section{Литература}

1. Yap TE, Balendra SI, Almonte MT, Cordeiro MF. Retinal correlates of neurological disorders. Ther Adv Chronic Dis. 2019; 10: 2040622319882205. doi:10.1177/2040622319882205

2. Cerveró A, Casado A, Riancho J. Retinal changes in amyotrophic lateral sclerosis: looking at the disease through a new window. J Neurol. 2021; 268 (6): 2083-9. DOI: 10.1007/s00415-01909654-w.

3. Rojas P, de Hoz R, Ramírez Al, et al. Changes in Retinal OCT and their correlations with neurological disability in early ALS Patients, a Follow-Up Study. Brain Sci. 2019; 9 (12): 337. DOI: 10.3390/ brainsci9120337.

4. Zarei S, Carr K, Reiley L, Diaz K, Guerra O, Altamirano PF, et al. A comprehensive review of amyotrophic lateral sclerosis. Surg Neurol Int. 2015; 16 (6): 171. DOI: 10.4103/2152-7806.169561.

5. Batra G, Jain M, Singh RS, Sharma AR, Singh A, Prakash A, et al. Novel therapeutic targets for amyotrophic lateral sclerosis. Indian J Pharmacol. 2019; 51 (6): 418-25. DOl: 10.4103/ijp.IJP_823_19.

6. Zou ZY, Che CH, Feng SY, Fang XY, Huang HP, Liu CY. Novel FUS mutation Y526F causing rapidly progressive familial amyotrophic lateral sclerosis. Amyotroph Lateral Scler Frontotemporal Degener. 2021; 22 (1-2): 73-79. DOI: 10.1080/21678421.2020.1797815.

7. Shelkovnikova TA, Peters OM, Deykin AV, et al. Fused in sarcoma
569-80. DOI: 10.3109/21678421.2014.951941.

19. Ringelstein $M$, Albrecht $P$, Sudmeyer $M$, et al. Subtle retinal pathology in amyotrophic lateral sclerosis. Ann Clin Transl Neurol. 2014; 1 (4): 290-7. DOl: 10.1002/acn3.46.

20. Rojas P, Ramírez Al, Fernández-Albarral JA, López-Cuenca I, Salobrar-García E, Cadena M, et al. Amyotrophic Lateral Sclerosis: A Neurodegenerative Motor Neuron Disease With Ocular Involvement. Front Neurosci. 2020; 14: 566858. DOI: 10.3389/fnins.2020.566858.

21. Crivello M, Hogg MC, Jirström E, Halang L, Woods I, Rayner M, et al. Vascular regression precedes motor neuron loss in the FUS (1-359) ALS mouse model. Dis Model Mech. 2019; 12 (8): dmm040238. DOI: 10.1242/dmm.040238.

22. Rudnick ND, Griffey CJ, Guarnieri P, Gerbino V, Wang X, Piersaint $\mathrm{JA}$, et al. Distinct roles for motor neuron autophagy early and late in the SOD1(G93A) mouse model of ALS. Proceedings of the National Academy of Sciences of the United States of America. 2017; 114: E8294-E8303.

23. Evans CS, Holzbaur ELF. Autophagy and mitophagy in ALS. Neurobiol Dis. 2019; 122: 35-40. DOI: 10.1016/j.nbd.2018.07.005.

24. Strohm L, Behrends C. Glia-specific autophagy dysfunction in ALS. Semin Cell Dev Biol. 2020; 99: 172-82. DOI: 10.1016/j. semcdb.2019.05.024.

25. Ghavami S, Shojaei S, Yeganeh B, Ande SR, Jangamreddy JR, Mehrpour M, et al. Autophagy and apoptosis dysfunction in neurodegenerative disorders. Prog Neurobiol. 2014; 112: 24-49. DOI: 10.1016/j.pneurobio.2013.10.004.

26. de Munter JPJM, Shafarevich I, Liundup A, Pavlov D, Wolters EC, Gorlova A, et al. Neuro-Cells therapy improves motor outcomes and suppresses inflammation during experimental syndrome of amyotrophic lateral sclerosis in mice. CNS Neurosci Ther. 2020; 26 (5): 504-17. DOI: $10.1111 / \mathrm{cns} .13280$.

27. Ninkina N. Stem cell therapy and FUS[1-359]-transgenic mice: A recent study highlighting a promising ALS model and a promising therapy. CNS Neurosci Ther. 2020; 26 (5): 502-3. DOI: 10.1111/ cns. 13302

28. Ramirez Al, de Hoz R, Salobrar-Garcia E, Salazar JJ, Rojas B, Ajoy D, et al. The Role of Microglia in Retinal Neurodegeneration: Alzheimer's Disease, Parkinson, and Glaucoma. Front Aging Neurosci. 2017; 9: 214. DOI: 10.3389/fnagi.2017.00214.

29. Dolzhikov AA, Bobyntsev II, Belykh AE, Shevchenko OA, Pobeda AS, Dolzhikova IN, et al. Pathogenesis of neurodegenerative pathology and new concepts of transport and metabolic systems of the brain and eye. Kursk Scientific and Practical Bulletin "Man and His Health". 2020; (1): 43-57. DOI: 10.21626/ vestnik/2020-1/06
(FUS) protein lacking nuclear localization signal (NLS) and major RNA binding motifs triggers proteinopathy and severe motor phenotype in transgenic mice. J Biol Chem. 2013; 288 (35): 25266-274. DOI: 10.1074/jbc.M113.492017.

8. Funikov SY, Rezvykh AP, Mazin PV, Morozov AV, Maltsev AV, Chicheva MM, et al. FUS(1-359) transgenic mice as a model of ALS: pathophysiological and molecular aspects of the proteinopathy. Neurogenetics. 2018; 19 (3): 189-204. DOl: 10.1007/s10048-018-0553-9.

9. Mukaratirwa S, Petterino C, Naylor SW, Bradley A. Incidences and Range of Spontaneous Lesions in the Eye of Crl:CD-1(ICR) BR Mice Used in Toxicity Studies. Toxicol Pathol. 2015; 43 (4): 530-5. DOI: 10.1177/0192623314548767.

10. De Groef L, Dekeyster E, Geeraerts E, Lefevere E, Stalmans I, Salinas-Navarro M, et al. Differential visual system organization and susceptibility to experimental models of optic neuropathies in three commonly used mouse strains. Exp Eye Res. 2016; 145: 235-47. DOI: 10.1016/i.exer.2016.01.006.

11. Hart NJ, Koronyo Y, Black KL, Koronyo-Hamaoui M. Ocular indicators of Alzheimer's: exploring disease in the retina. Acta Neuropathol. 2016; 132 (6): 767-87. DOI: 10.1007/s00401-0161613-6. 
12. Mohana Devi S, Mahalaxmi I, Aswathy NP, Dhivya V, Balachandar V. Does retina play a role in Parkinson's Disease? Acta Neurol Belg. 2020; 120 (2): 257-65. DOI: 10.1007/s13760-020-01274-w.

13. Huang L, Zhang D, Ji J, Wang $Y$, Zhang R. Central retina changes in Parkinson's disease: a systematic review and meta-analysis. J Neurol. 2020; 10. DOI: 10.1007/s00415-020-10304-9.

14. Harrison IF, Whitaker R, Bertelli PM, O'Callaghan JM, Csincsik L, Bocchetta $\mathrm{M}$, et al. Optic nerve thinning and neurosensory retinal degeneration in the rTg4510 mouse model of frontotempora dementia. Acta Neuropathol Commun. 2019; 7 (1): 4. DOl: 10.1186/s40478-018-0654-6.

15. Soldatov VO, Kukharsky MS, Belykh AE, Sobolev AM, Deykin AV. Retinal Damage in Amyotrophic Lateral Sclerosis: Underlying Mechanisms. Eye Brain. 2021; 13: 131-46. DOI: 10.2147/ EB.S299423.

16. Boven L, Jiang QL, Moss HE. Diffuse colour discrimination as marker of afferent visual system dysfunction in amyotrophic lateral sclerosis. Neuroophthalmology. 2017; 41 (6): 310-4. DOI: 10.1080/01658107.2017.1326153.

17. Rohani M, Meysamie A, Zamani B, Sowlat MM, Akhoundi FH. Reduced retinal nerve fiber layer (RNFL) thickness in ALS patients: a window to disease progression. J Neurol. 2018; 265 (7): 155762. DOI: 10.1007/s00415-018-8863-2.

18. Fawzi AA, Simonett JM, Purta P, et al. Clinicopathologic report of ocular involvement in ALS patients with C9orf72 mutation. Amyotroph Lateral Scler Frontotemporal Degener. 2014; 15 (7-8): 569-80. DOI: 10.3109/21678421.2014.951941.

19. Ringelstein $M$, Albrecht $P$, Sudmeyer $M$, et al. Subtle retinal pathology in amyotrophic lateral sclerosis. Ann Clin Transl Neurol 2014; 1 (4): 290-7. DOI: 10.1002/acn3.46.

20. Rojas P, Ramírez Al, Fernández-Albarral JA, López-Cuenca I, Salobrar-García E, Cadena M, et al. Amyotrophic Lateral Sclerosis: A Neurodegenerative Motor Neuron Disease With Ocular Involvement. Front Neurosci. 2020; 14: 566858. DOI: 10.3389/fnins.2020.566858.

21. Crivello M, Hogg MC, Jirström E, Halang L, Woods I, Rayner M, et al. Vascular regression precedes motor neuron loss in the FUS (1-359) ALS mouse model. Dis Model Mech. 2019; 12 (8): dmm040238. DOI: 10.1242/dmm.040238.

22. Rudnick ND, Griffey CJ, Guarnieri P, Gerbino V, Wang X, Piersaint $J A$, et al. Distinct roles for motor neuron autophagy early and late in the SOD1(G93A) mouse model of ALS. Proceedings of the National Academy of Sciences of the United States of America. 2017; 114: E8294-E8303.

23. Evans CS, Holzbaur ELF. Autophagy and mitophagy in ALS. Neurobiol Dis. 2019; 122: 35-40. DOI: 10.1016/j. nbd.2018.07.005.

24. Strohm L, Behrends C. Glia-specific autophagy dysfunction in ALS. Semin Cell Dev Biol. 2020; 99: 172-82. DOI: 10.1016/j. semcdb.2019.05.024.

25. Ghavami S, Shojaei S, Yeganeh B, Ande SR, Jangamreddy JR, Mehrpour M, et al. Autophagy and apoptosis dysfunction in neurodegenerative disorders. Prog Neurobiol. 2014; 112: 24-49. DOI: 10.1016/j.pneurobio.2013.10.004.

26. de Munter JPJM, Shafarevich I, Liundup A, Pavlov D, Wolters EC, Gorlova A, et al. Neuro-Cells therapy improves motor outcomes and suppresses inflammation during experimental syndrome of amyotrophic lateral sclerosis in mice. CNS Neurosci Ther. 2020; 26 (5): 504-17. DOl: 10.1111/cns.13280.

27. Ninkina N. Stem cell therapy and FUS[1-359]-transgenic mice: A recent study highlighting a promising ALS model and a promising therapy. CNS Neurosci Ther. 2020; 26 (5): 502-3. DOI: 10.1111/ cns. 13302

28. Ramirez Al, de Hoz R, Salobrar-Garcia E, Salazar JJ, Rojas B, Ajoy D, et al. The Role of Microglia in Retinal Neurodegeneration: Alzheimer's Disease, Parkinson, and Glaucoma. Front Aging Neurosci. 2017; 9: 214. DOI: 10.3389/fnagi.2017.00214.

29. Dolzhikov AA, Bobyntsev II, Belykh AE, Shevchenko OA, Pobeda AS, Dolzhikova IN, et al. Pathogenesis of neurodegenerative pathology and new concepts of transport and metabolic systems of the brain and eye. Kursk Scientific and Practical Bulletin "Man and His Health". 2020; (1): 43-57. DOI: 10.21626/vestnik/2020-1/06. 